\title{
Oxidative weathering of a copper sulphide ore and its influence on pulp chemistry and flotation
}

\author{
S. Jacques ${ }^{\mathrm{a}, *}$, C.J. Greet ${ }^{\mathrm{b}}$, D. Bastin ${ }^{\mathrm{c}}$ \\ ${ }^{a}$ Magotteaux Andino SA, Panamericana Norte Km. $37 \mathrm{~S} / \mathrm{N}^{\circ}$, Til-Til, Santiago, Chile \\ ${ }^{\mathrm{b}}$ Minerals Processing Research, Magotteaux Australia Pty Ltd, PO Box 54, Mansfield Park, SA 5012, Australia \\ ' University of Liège, Laboratory of Minerals Engineering and Recycling, Sart-Tilman Campus-B52, 4000 Liège, Belgium
}

\section{A R T I C L E I N F O}

\section{Article history:}

Received 9 August 2016

Accepted 25 September 2016

Available online 1 October 2016

\section{Keywords:}

Sulphide flotation

Ore oxidation

Grinding chemistry

\begin{abstract}
A B S T R A C T
The influence of grinding chemistry on the flotation behaviour of sulphides minerals has been widely studied. However, its influence on partially oxidised sulphide ores is not well documented. Various oxidation events can affect a sulphide ore, either during in situ weathering of an ore body or during the different extraction and processing stages (mining operations, stockpiling, crushing, milling and flotation). In this study, a hypogene copper sulphide ore was artificially oxidised to various lengths of time by percolating a small quantity of acidic ferric sulphate solution inoculated with a mixed bacterial culture through packed columns. For each time interval a series of grinding-flotation tests using different grinding media alloys was completed. The grinding and flotation chemistry were compared and linked to the flotation behaviour of the ore samples.

The results reveal that as oxidation progressed the copper metallurgy deteriorated. However, the deleterious effects of oxidation could be partially overcome through the application of the right grinding chemistry.
\end{abstract}

(c) 2016 Elsevier Ltd. All rights reserved.

\section{Introduction}

The importance of pulp chemistry in sulphide mineral flotation and its role in the selective flotation of chalcopyrite against pyrite has been well documented. Pulp chemical conditions and especially the electrochemistry play an important role in mineral collector interactions and in the nature and composition of the species present at the mineral surface (Tolley et al., 1996; Woods 2003, 2010; Ekmekçi et al., 2005). More specifically, the grinding chemistry through electrochemical interactions between grinding media and sulphide minerals is known to markedly affect the subsequent sulphide flotation. A great number of works on this subject are reported in the literature (Adam et al., 1984; Bruckward et al., 2011; Gonçalves et al., 2003; Greet et al., 2004; Huang and Grano, 2005a, 2005b; Ekmekçi et al., 2005; Grano, 2009). Carbon steel grinding media, through galvanic interactions and oxidationreductive reactions, are responsible for the precipitation of iron oxyhydroxy species at the sulphide surfaces, along with pulp dissolved oxygen (DO) scavenging and lowering of pulp electrochemical potential (Eh), leading to poor sulphide floatability.

\footnotetext{
* Corresponding author.

E-mail addresses: Simon.jacques@magotteaux.com (S. Jacques), Christopher. greet@magotteaux.com (C.J. Greet), David.Bastin@ulg.ac.be (D. Bastin).
}

The use of less electrochemically active grinding media (such as high chromium alloys) can counteract the deleterious effects of more electrochemically active grinding media (such as forged steel media) on sulphide flotation. They can reduce the quantity of iron oxidation products and increase the pulp electrochemical potential and oxygen content, improving the collector-sulphide interactions. Bruckward et al. (2011) reported that the pulp chemical environment, ore composition, properties and type of grinding media, pre-conditioning stages and reagent addition during grinding could influence the subsequent flotation process.

Surface oxidation of sulphide minerals is known to adversely affect the flotation and separation of chalcopyrite from pyrite since sulphide flotation depends on the proportion of hydrophobic and hydrophilic species covering the surfaces (Smart, 1991; Guy and Trahar, 1985). Due to their electrochemical properties, the surfaces of the sulphide minerals start oxidising as soon as they are in contact with oxygen or water, due to electrochemical interactions that occur between sulphide minerals or solution species, affecting their subsequent recovery (Ralston et al., 2007; Peng and Zhao, 2011; Owusu et al., 2014). Various oxidation events can affect a sulphide ore, either during in situ weathering of an ore body or during the different extraction and processing stages (mining operations, stockpiling, crushing, milling and flotation) (Clark et al., 2000). Chalcopyrite surface oxidation leads to, in the first instance, 
dissolution of $\mathrm{Cu}$ and $\mathrm{Fe}$ ions from the mineral surface leaving a metal deficient layer enriched in sulphur on the surface, with some metal hydroxide present in alkaline conditions (Owusu et al., 2014; Peng et al., 2003; Todd et al., 2003; Peng and Zhao, 2011). Since collectorless flotation is attributed to the presence of sulphur rich species such as polysulphide or elemental sulphide (Lutrell and Yoon, 1984a,b; Barzyk et al., 1981; Walker et al., 1986), slight surface oxidation may enhance the flotation performance of the sulphide mineral (Buckley and Woods, 1984; Smart, 1991; Smart et al., 1998; Vaughan et al., 1995). However, the presence of dissolved $\mathrm{Cu}$ ions also promotes pyrite flotation through $\mathrm{Cu}$ adsorption on their surface (i.e. copper activation of pyrite (Von Oertzen et al., 2007; Chandra and Gerson, 2009; Lascelles and Finch, 2002), adversely affecting the selectivity of chalcopyrite flotation against pyrite and decreasing the copper concentrate grade. Further oxidation leads to precipitation of a higher quantity of iron hydroxides (in alkaline conditions) covering the metal deficient sulphur rich surface, decreasing the flotation response of the sulphide minerals. Indeed increasing the amount of hydrophilic metal hydroxides decreases the hydrophobicity of the mineral and alters the collector adsorption making it less selective toward the various sulphide minerals (Senior and Trahar, 1991; Clarke et al., 1995).

In this study, a copper sulphide ore has been artificially oxidised for varying lengths of time and a series of grinding and flotation tests under several grinding environments were completed at each time interval to study the combined effect of ore oxidation and grinding pulp chemistry. The results highlight the importance of matching the right grinding environment to the oxidation degree of the ore.

\section{Experimental}

\subsection{Materials}

A sample of approximately $600 \mathrm{~kg}$ of copper sulphide ore was sourced from the plant feed conveyor from an Australian copper mine. Mineralogical analysis of the ore revealed that copper was present as chalcopyrite only. Pyrite was the main iron sulphide mineral with small amounts of pyrrhotite. The ore was received as a mixture of coarse and fine material. Once received it was crushed to $100 \%$ passing to $2 \mathrm{~mm}$. A total of seven representative samples were prepared. One (T0) was kept aside as the baseline, while the other six were packed into the columns. Initially the columns were moistened by hosing the top of the column with water until water escaped from the bottom of the column. Then, they were artificially oxidised for varying lengths of time (15 days, 1 , $2,4,8$ and 16 months) by percolating $70 \mathrm{ml}$ per day of acidic ferric sulphate ( $9 \mathrm{~g} / \mathrm{l}$ of ferric $\mathrm{Fe}$ ) solution inoculated with a mixed bacterial culture through packed columns. Bacteria were used, mainly to catalyse the conversion of ferrous into ferric ions, but also because of their possible direct implication in sulphide oxidation (Watling, 2006; Boon, 2001). This effectively oxidised the ore and produced increasingly more oxidising conditions as the treatment time increased. Holes were drilled at the bottom of each column to allow excess solution to escape. The excess solution was regularly assayed to control the quantity of iron and copper that was being leached into the solution. The temperature of the entire equipment was maintained at $35^{\circ} \mathrm{C}$ in a closed room.

The sample identification, oxidation time and head assay are presented in Table 1. Once oxidised, each sample was thoroughly mixed and split into $2.2 \mathrm{~kg}$ lots. Each sub-sample was placed in a plastic bag, sealed and stored in a freezer prior to use to minimise any further oxidation. The charge weight was chosen to achieve the target percent solids for rougher flotation.
Table 1

Sample identification, oxidation time and head assay.

\begin{tabular}{lllllll}
\hline Sample ID & Oxidation time & \multicolumn{6}{l}{ Head assays, $\%$} \\
\cline { 3 - 7 } & & $\mathrm{Cu}$ & $\mathrm{Fe}$ & $\mathrm{S}$ & $\mathrm{IS}$ & NSG \\
\hline T0 & 0 & 0.47 & 11.56 & 2.14 & 3.13 & 95.5 \\
T1 & 15 days & 0.48 & 11.22 & 2.10 & 3.02 & 95.6 \\
T2 & 1 month & 0.46 & 11.20 & 2.06 & 2.98 & 95.6 \\
T3 & 2 months & 0.47 & 11.30 & 2.04 & 2.93 & 95.7 \\
T4 & 4 months & 0.47 & 11.47 & 2.01 & 2.88 & 95.7 \\
T5 & 8 months & 0.45 & 10.80 & 1.97 & 2.83 & 95.8 \\
T6 & 16 months & 0.48 & 10.75 & 2.04 & 2.92 & 95.7 \\
\hline
\end{tabular}

\subsection{Grinding and flotation tests}

A series of grinding and flotation tests under several grinding environments were completed for each sample. The test procedure was the same for all samples tested. Grinding was completed using the Magotteaux Mill ${ }^{\circledR}$ which allows the control and monitoring of the pulp chemistry during grinding (Greet et al., 2004). A $2200 \mathrm{~g}$ sample of ore was ground with $2 \mathrm{~L}$ of tap water and $10 \mathrm{~kg}$ of the desired grinding media to achieve a $\mathrm{P}_{80}$ of $185 \mu \mathrm{m}$. The mill speed was adjusted for the seven ores as well as for each alloy tested to keep the particle distribution the same for each condition. The Magotteaux Mill ${ }^{\circledR}$ discharge pulp chemistry was calibrated with forged steel media and the fresh ore sample (T0) and the grinding procedure then kept constant for all media and ores tested. After grinding, the pulp was transferred into a $5 \mathrm{~L}$ Magotteaux flotation cell and homogenised during two minutes. The $\mathrm{pH}$ was then adjusted to 10.3 with lime. The pulp was conditioned for $1 \mathrm{~min}$ with $10 \mathrm{~g} / \mathrm{t}$ of Aero3418A collector, followed by 5 drops of MIBC frother for $1 \mathrm{~min}$. Following conditioning, four timed copper rougher concentrates were collected for $0.5,1.5,3$ and $5 \mathrm{~min}$, for a total flotation time of $10 \mathrm{~min}$. The froth was hand scraped every $10 \mathrm{~s}$. Tap water was added during the flotation to maintain the pulp level in the flotation cell. The pulp chemistry (Eh, pH, DO and Temperature) was recorded using a 90 MLF TPS meter during grinding, before and after flotation. All tests were completed in triplicate to obtain confidence in the data produced. The reproducibility was examined for each condition and tests repeated if necessary.

\subsection{Chemical analysis}

All liquid and solid samples were assayed at Bureau Veritas chemical laboratory in Adelaide, Australia. Liquids were assayed for copper and iron. All solid samples were assayed for copper, iron and sulphur. Iron sulphide (IS) and non-sulphide gangue (NSG) were deducted from the elemental assays using the following equations:

$$
\begin{aligned}
\% \mathrm{Cp}(\text { Chalcopyrite })= & \% \mathrm{Cu} \times(183.3 / 63.5) \\
\% \mathrm{IS}(\text { Iron Sulphide })= & (\% \mathrm{~S}-(2 \times 32.06 / 183.3) \times \% \mathrm{Cp}) \\
& \times(119.85 / 2 \times 32.06)
\end{aligned}
$$

$\%$ NSG (Non-sulphide Gangue $)=100-\%$ IS $-\%$ Cp

\subsection{EDTA extraction}

Ethylenediamine tetra acetic acid disodium salt (EDTA) extractions were performed for each test to measure the quantity of the $\mathrm{Cu}$ and Fe oxidation products present in the slurry and on the mineral surfaces. A sample of $25 \mathrm{ml}$ of flotation feed was stirred under nitrogen for 5 min with a w/w 3\% solution of EDTA adjusted to a $\mathrm{pH}$ 


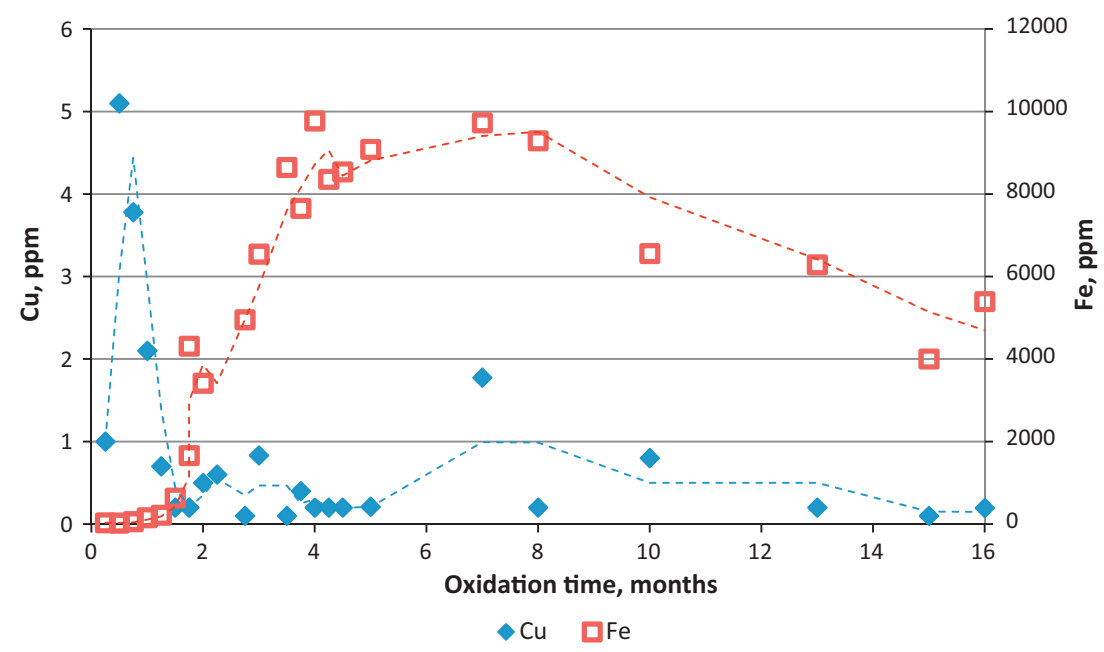

Fig. 1. Copper and iron content in the solution escaping the columns versus oxidation time.

of 7.5. The sample was then filtered through a $0.45 \mu \mathrm{m}$ Millipore membrane and the pregnant solution analysed for $\mathrm{Cu}$ and Fe. The percentage of iron and copper extracted by EDTA were calculated as a ratio of the EDTA soluble copper or iron to the total amount of copper or iron present in the solid sample (Rumball and Richmond, 1996).

\subsection{Data analysis}

A metallurgical balance was performed for each test for $\mathrm{Cu}, \mathrm{Fe}$, $S$, iron sulphide (IS) and non-sulphide gangue (NSG). First order flotation rate constants and maximum recoveries were calculated using the first order kinetic model, and used to determine the impact of sample oxidation and grinding environment on the metallurgical performances of the ore. Rougher flotation can be considered as a first order kinetics process; recovery being a function of the time $(t)$ in the process and a flotation rate constant $(k)$, and calculated following Eq. (4):

$R_{t}=R_{\max }\left(1-e^{-k t}\right)$

where $\mathrm{R}_{\mathrm{t}}=$ recovery at time $t, \mathrm{R}_{\max }$ is the maximum recovery at infinite time and $k$ is the first order rate constant $\left(\mathrm{min}^{-1}\right)$.

In addition to this, the modified flotation rate constants $K_{M}$ were calculated for copper and iron sulphide by multiplying $R_{\max }$ and $k$. The copper/iron sulphide selectivity index $\left(\mathrm{SI}_{\mathrm{Cu} / \mathrm{IS}}\right)$ was calculated based on the following Eq. (5) (Xu, 1998) and used for results comparison.

$S I_{C u / I S}=\frac{K_{M} C u}{K_{M} I S}$

\section{Results}

\subsection{Analysis of the percolating solution}

The solution escaping the columns was assayed regularly to control the copper and iron content leached into the solution. The data are plotted in Fig. 1 in function of the oxidation time.

Overall the results show that a very low level of copper was leached into solution with values lower than $1 \mathrm{ppm}$ through most of the oxidation time. The exception to this was during the first month of oxidation. At the start of the oxidation process, the data shows a peak of copper into the solution higher than $5 \mathrm{ppm}$. This period most probably corresponds to chalcopyrite surface oxida- tion (rapidly stopped by surface passivation) or to surface cleaning where the acidic solution is removing the unstable copper oxidised product from the chalcopyrite surface. Dissolution of other copper soluble minerals present in trace amounts in the ore could also be responsible for the high quantity of copper leached at the start of the oxidation period.

Concerning iron, the first 4 months are characterised by iron precipitation within the column, probably through acid neutralisation by the gangue. After complete neutralisation, the maximum iron content in the solution is reached at around $9 \mathrm{~g}$ per litre (the concentration of the solution injected) after 7 months. The next period is then characterised by a decrease of iron in the solution.

\subsection{Pulp chemistry measurement}

The pulp chemistry at the ball mill discharge and the flotation feed at each oxidation time and for both grinding environments (forged steel and 21\% chromium alloy) are tabulated in Tables 2 and 3, respectively. Similarly, the copper and iron extracted by EDTA are presented in Table 4.

In terms of pulp chemistry, the data indicates that at each oxidation time, the high chrome alloy produced a more oxidising pulp chemistry with higher pulp potential (Eh) and dissolved oxygen (DO) content than forged steel media, not only at the ball mill discharge (Table 2) but also at the flotation feed (Table 3). The $\mathrm{pH}$ was kept constant and the temperature was similar in all instances.

Looking in more details, Table 2 indicates that during the first month of oxidation, the pulp becomes more oxidising (higher Eh and DO) for both media types. Then, as oxidation progresses, at the point of complete neutralisation (T2), the Eh markedly drops. Examining the pulp electrochemical potential (Eh) and dissolved oxygen (DO) values obtained for both grinding environments reveals that the magnitude of the changes are more pronounced with forged steel than high chrome media; high chrome media delivering a more stable pulp chemistry independent of the oxidative processes that are taking place in the columns during the 16 months of the experiment. Whilst during the first month of oxidation (T1 and T2) the Eh and DO are very similar for both media, the difference in Eh and DO between forged steel and high chrome media becomes more accentuated with increased oxidation time (T3, T4 and to a lesser extent T5 samples). At the end of the oxidative process when the ore is heavily oxidised (T6), the Eh and DO once again become similar between high chrome and forged steel media. 
Table 2

Ball mill discharge pulp chemistry versus oxidation time for the tests completed with forged steel and high chrome media.

\begin{tabular}{|c|c|c|c|c|c|c|c|c|}
\hline \multirow[t]{2}{*}{ Sample ID } & \multicolumn{2}{|c|}{ Eh, mV (SHE) } & \multicolumn{2}{|c|}{$\mathrm{DO}, \mathrm{ppm}$} & \multicolumn{2}{|c|}{$\mathrm{pH}$} & \multicolumn{2}{|c|}{ Temperature $\left({ }^{\circ} \mathrm{C}\right)$} \\
\hline & Forged & $\mathrm{HiCr}$ & Forged & $\mathrm{HiCr}$ & Forged & $\mathrm{HiCr}$ & Forged & $\mathrm{HiCl}_{1}$ \\
\hline T0 & 155 & 171 & 1.7 & 2.4 & 9.3 & 9.3 & 27.5 & 26.8 \\
\hline $\mathrm{T} 1$ & 264 & 242 & 2.2 & 2.5 & 9.3 & 9.3 & 27.4 & 26.7 \\
\hline $\mathrm{T} 2$ & 238 & 263 & 2.0 & 2.3 & 9.4 & 9.3 & 28.9 & 27.3 \\
\hline T3 & 34 & 177 & 1.5 & 2.9 & 9.4 & 9.3 & 26.7 & 26.7 \\
\hline $\mathrm{T} 4$ & 26 & 157 & 1.2 & 1.8 & 9.4 & 9.4 & 28.8 & 29.9 \\
\hline $\mathrm{T} 5$ & 122 & 220 & 1.0 & 2.2 & 9.4 & 9.4 & 27.8 & 26.4 \\
\hline T6 & 224 & 243 & 2.3 & 2.5 & 9.4 & 9.4 & 27.7 & 26.2 \\
\hline
\end{tabular}

Table 3

Flotation feed pulp chemistry versus oxidation time for the tests completed with forged steel and high chrome media.

\begin{tabular}{|c|c|c|c|c|c|c|c|c|}
\hline \multirow[t]{2}{*}{ Sample ID } & \multicolumn{2}{|c|}{ Eh, mV (SHE) } & \multicolumn{2}{|c|}{ DO, ppm } & \multicolumn{2}{|c|}{$\mathrm{pH}$} & \multicolumn{2}{|c|}{ Temperature $\left({ }^{\circ} \mathrm{C}\right)$} \\
\hline & Forged & $\mathrm{HiCr}$ & Forged & $\mathrm{HiCr}$ & Forged & $\mathrm{HiCr}$ & Forged & $\mathrm{HiCr}$ \\
\hline T0 & 93 & 166 & 3.5 & 7.0 & 10.3 & 10.3 & 27.0 & 26.0 \\
\hline $\mathrm{T} 1$ & 106 & 170 & 5.1 & 7.2 & 10.3 & 10.2 & 28.4 & 27.9 \\
\hline $\mathrm{T} 2$ & 155 & 166 & 6.3 & 7.3 & 10.3 & 10.3 & 28.9 & 28.5 \\
\hline T3 & 145 & 174 & 5.7 & 6.8 & 10.4 & 10.3 & 27.8 & 29.1 \\
\hline $\mathrm{T} 4$ & 130 & 159 & 5.7 & 6.6 & 10.5 & 10.3 & 28.4 & 29.4 \\
\hline T5 & 183 & 221 & 6.6 & 7.4 & 10.3 & 10.3 & 27.0 & 26.0 \\
\hline T6 & 185 & 191 & 7.4 & 8.1 & 10.4 & 10.3 & 23.0 & 22.0 \\
\hline
\end{tabular}

Table 4

Copper and iron extracted by EDTA versus oxidation time for the tests completed with forged steel and high chrome media.

\begin{tabular}{llllll}
\hline \multirow{2}{*}{ Sample ID } & \multicolumn{2}{c}{$\mathrm{Cu} \%$} & & \multicolumn{2}{c}{$\mathrm{Fe}, \%$} \\
\cline { 2 - 3 } \cline { 5 - 6 } & Forged & $\mathrm{HiCr}$ & & Forged & $\mathrm{HiCr}$ \\
\hline T0 & 0.09 & 0.11 & 0.37 & 0.07 \\
T1 & 0.09 & 0.13 & 0.31 & 0.10 \\
T2 & 0.08 & 0.13 & 0.31 & 0.09 \\
T3 & 0.06 & 0.09 & & 0.29 & 0.07 \\
T4 & 0.07 & 0.09 & 0.27 & 0.06 \\
T5 & 0.07 & 0.10 & 0.24 & 0.07 \\
T6 & 0.08 & 0.30 & 0.18 & 0.05 \\
\hline
\end{tabular}

Turning to flotation feed chemistry (Table 3), the data indicates that overall, the pulp chemistry conditions became more oxidising with increased oxidation time (higher Eh and DO). When comparing forged steel and high chrome media, the data shows that during the first month of oxidation (until T2), the Eh and DO of the forged steel media strongly increased, minimising the chemistry difference between the two media types. With time (T3 to T6), as ore oxidation progresses, the Eh and DO increase similarly for both media and reach equal levels (particularly the Eh) by the end of the experiment.

Interestingly, the EDTA data (Table 4) shows a quite constant level of copper extracted by EDTA for the different oxidation times (except with T6 samples which show a strong increase of Cu EDTA extracted with high chrome media); forged steel media showing slightly lower percentages of EDTA copper than high chrome media. Slightly higher Cu EDTA extractable values at the beginning of the experiments could be related to partial adsorption of the $\mathrm{Cu}$ leached during the first month. The EDTA extractable iron shows a different behaviour: while high chrome grinding media has concentrations of just below $0.1 \%$, the forged steel data shows much higher values at the start of the oxidation process ( $0.4 \%$ at $\mathrm{T} 0$ ), then decreases as the oxidation time increases to reach $0.2 \%$ at T6. This is could be attributed to the formation of more stable iron oxide species with oxidation time (less soluble in EDTA) or to a decrease in the quantity of the galvanic interactions taking place between the media and the partially oxidised sulphide minerals.

\subsection{Flotation results}

The copper and iron sulphide maximum recoveries and first order rate constant at each oxidation time are tabulated in Table 5. The copper $\left(\mathrm{K}_{\mathrm{M}} \mathrm{Cu}\right)$ and iron sulphide $\left(\mathrm{K}_{\mathrm{M}} \mathrm{IS}\right)$ modified rate constant and the copper/iron sulphide selectivity index ( $\mathrm{SI}_{\mathrm{Cu} / \mathrm{IS}}$ ) were deduced from the first order kinetic data. They are plotted versus oxidation time in Figs. 2 and 3 respectively.

Overall, the data in Table 5 indicates that as expected, ore oxidation adversely affected the copper metallurgy, with the maximum copper recovery decreasing from around $90 \%$ with the T0 sample down to $65 \%$ after 16 months of oxidation (T6). Comparing the two grinding environments, the data indicates that high chrome media produced better maximum copper recovery and flotation rate constants at each oxidation time except with the most heavily oxidised sample (T6) where both media show similar results.

Looking more deeply at the results in Fig. 2, it appears that 3 different periods can be distinguished. They correspond to weak, medium and strong mineral oxidation. At the start (T0), the trends in Fig. 2 show much higher copper and iron sulphide modified rate constants with high chrome than forged steel media. While with high chrome media the modified rate constant for copper was much higher than that of iron sulphides, with forged steel media they are similar, lowering the selectivity between copper and iron sulphides. During the initial period of oxidation (weak oxidation: $\mathrm{T} 1$ and T2), it appears that the pyrite was strongly activated; the iron sulphide modified rate constant reaching its maximum at T2 with both media. While with high chrome media the $\mathrm{Cu}$ modified rate constant was poorly affected, it peaked at $\mathrm{T} 2$ with forged steel media. During the second period (medium oxidation: T3, T4 and $\mathrm{T} 5$ ), the ore oxidation progressed, pyrite activation decreased and chalcopyrite flotation became more adversely affected. That is, the iron sulphide and copper modified rate constants deceased with both media. Finally, the third period corresponds to strong ore oxidation (T6). The metallurgical performances of the ore ground with high chrome and forged steel media became closer with Fig. 2 showing similar copper modified rate constants for both media. However for the first time in the experiment, the iron sulphides modified rate constant for forged steel media became slightly higher than that of high chrome media. 
Table 5

Copper and iron sulphide maximum recovery and flotation rate constant versus oxidation time for the tests completed with forged steel and high chrome media.

\begin{tabular}{|c|c|c|c|c|c|c|c|c|}
\hline \multirow[t]{3}{*}{ Sample ID } & \multicolumn{4}{|c|}{ Copper } & \multicolumn{4}{|c|}{ Iron Sulphide (IS) } \\
\hline & \multicolumn{2}{|c|}{$\mathrm{R}_{\max }, \%$} & \multicolumn{2}{|c|}{$\mathrm{k}, \min ^{-1}$} & \multicolumn{2}{|c|}{$\mathrm{R}_{\max }, \%$} & \multicolumn{2}{|c|}{$\mathrm{k}, \min ^{-1}$} \\
\hline & Forged & $\mathrm{HiCr}$ & Forged & $\mathrm{HiCr}$ & Forged & $\mathrm{HiCr}$ & Forged & $\mathrm{HiCr}$ \\
\hline T0 & 88.8 & 92.4 & 1.0 & 4.3 & 26.8 & 31.6 & 0.6 & 1.3 \\
\hline $\mathrm{T} 1$ & 83.8 & 89.7 & 0.6 & 4.0 & 39.3 & 45.5 & 1.0 & 1.6 \\
\hline $\mathrm{T} 2$ & 84.2 & 89.4 & 1.9 & 4.2 & 43.7 & 47.7 & 1.2 & 1.7 \\
\hline T3 & 84.7 & 88.8 & 0.8 & 4.2 & 38.3 & 43.0 & 1.1 & 1.7 \\
\hline $\mathrm{T} 4$ & 81.9 & 86.1 & 1.1 & 3.2 & 38.1 & 42.4 & 0.7 & 1.1 \\
\hline T5 & 73.4 & 82.4 & 1.0 & 3.2 & 35.6 & 36.8 & 0.7 & 1.0 \\
\hline T6 & 65.2 & 65.4 & 2.1 & 2.2 & 26.8 & 24.3 & 0.9 & 0.9 \\
\hline
\end{tabular}

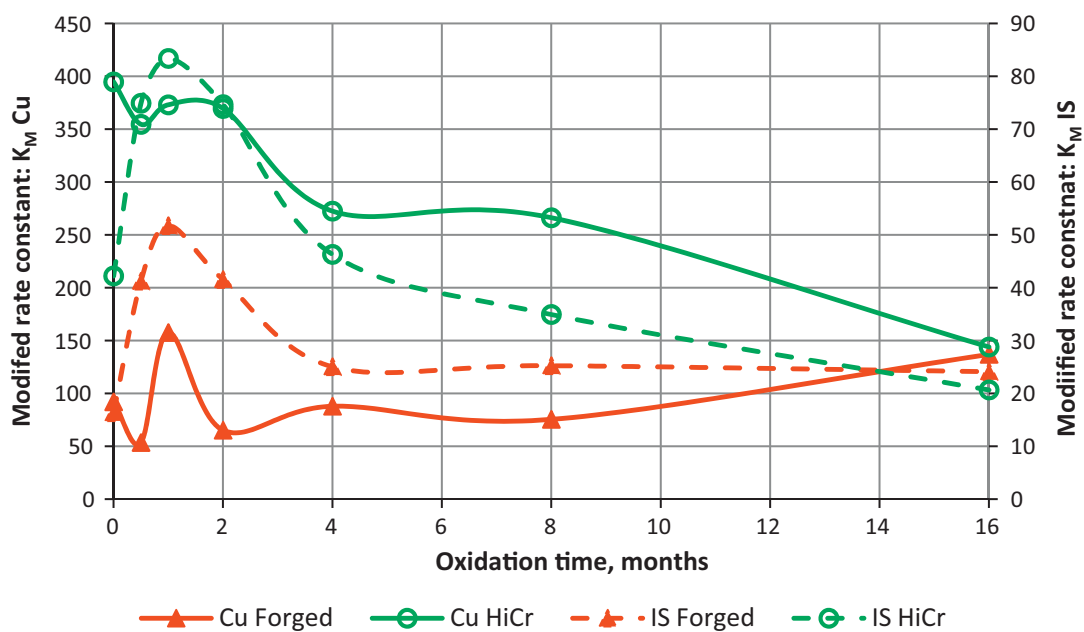

Fig. 2. Copper $\left(\mathrm{K}_{\mathrm{M}} \mathrm{Cu}\right)$ and iron sulphide $\left(\mathrm{K}_{\mathrm{M}} \mathrm{IS}\right)$ modified rate constant versus oxidation time for tests completed with forged steel and high chrome media.

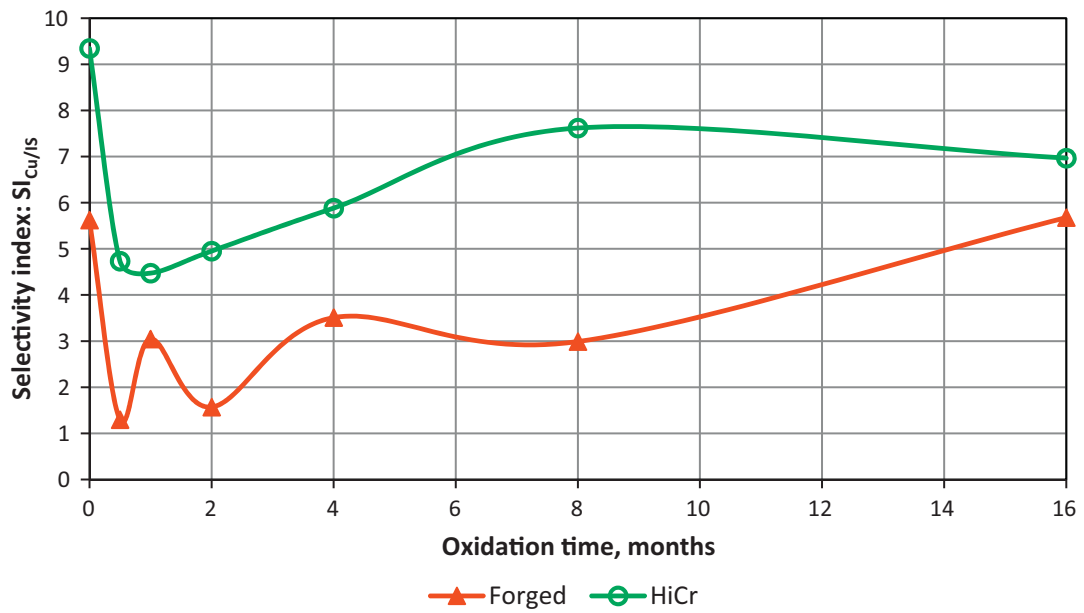

Fig. 3. $\mathrm{SI}_{\mathrm{Cu} / \mathrm{IS}}$ selectivity index versus oxidation time for tests completed with forged steel and high chrome media.

Now considering the $\mathrm{SI}_{\mathrm{Cu} / \mathrm{IS}}$ trends in Fig. 3, these show that overall, high chrome media produced a superior selectivity index than forged steel media independent of the oxidation degree of the ore. The pyrite activation is clearly marked with a strong decrease in the selectivity index during the first month of oxidation with both media tested. As oxidation progresses, pyrite seems more affected than chalcopyrite, resulting in an increase in selectivity with accentuated differences between forged steel and high chrome media. Finally, at the end of the oxidation period, the data shows that the selectivity of chalcopyrite against iron sulphide is still better with high chrome media but to a lesser extent than that observed initially.

\subsection{Size by size recovery}

The flotation products of selected experiments were sized and assayed to allow recovery by size calculation. The copper and iron sulphide feed distributions are presented in Table 6 . The size by 
Table 6

Copper and iron sulphide feed distribution by size.

\begin{tabular}{|c|c|c|c|c|c|c|c|c|}
\hline \multirow[t]{2}{*}{ Element } & \multicolumn{7}{|c|}{ Standard size range, microns } & \multirow[t]{2}{*}{ Total } \\
\hline & $-\mathrm{C} 6$ & $-\mathrm{C} 4 /+\mathrm{C} 6$ & $-\mathrm{C} 3 /+\mathrm{C} 4$ & $-\mathrm{C} 2 /+\mathrm{C} 3$ & $-75 /+C 2$ & $-150 /+75$ & $>150$ & \\
\hline $\mathrm{Cu}, \%$ & 7.6 & 3.1 & 5.3 & 26.2 & 31.7 & 18.3 & 7.8 & 100 \\
\hline IS, $\%$ & 5.7 & 2.1 & 3.6 & 23.2 & 31.4 & 20.9 & 13.1 & 100 \\
\hline
\end{tabular}

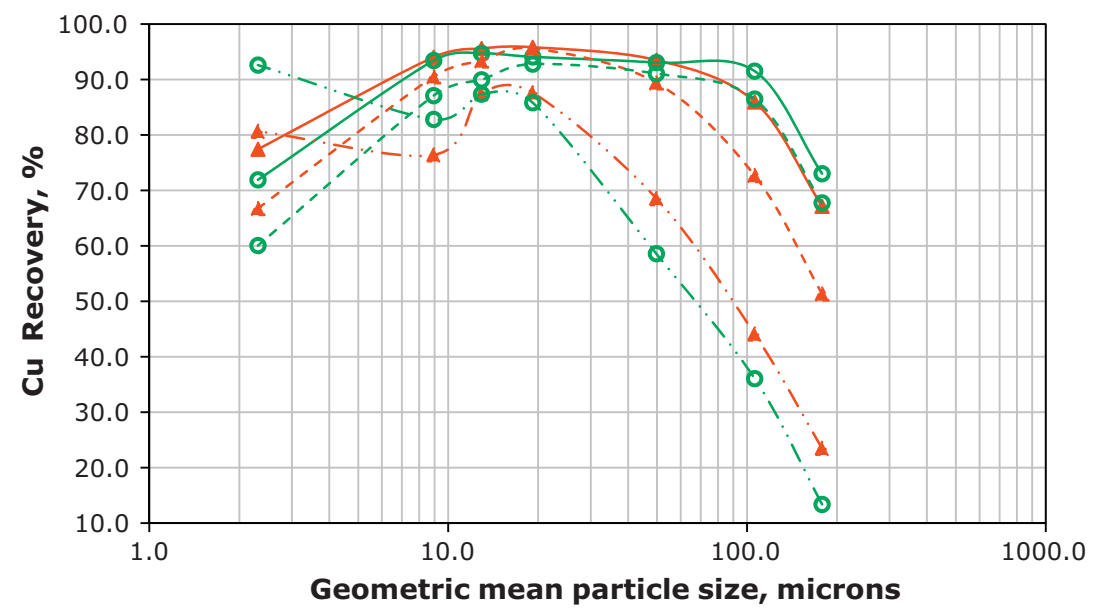

\begin{tabular}{|lll|}
\hline- Forged T0 & $-\bullet-$ HiCr T0 & $--\star-$ Forged T1 \\
$-\diamond-$ HiCr T1 & $-\star-$ Forged T6 & - o-HiCr T6 \\
\hline
\end{tabular}

Fig. 4. Copper size by size recovery for T0, T1 and T6 samples ground with forged steel and high chrome media.

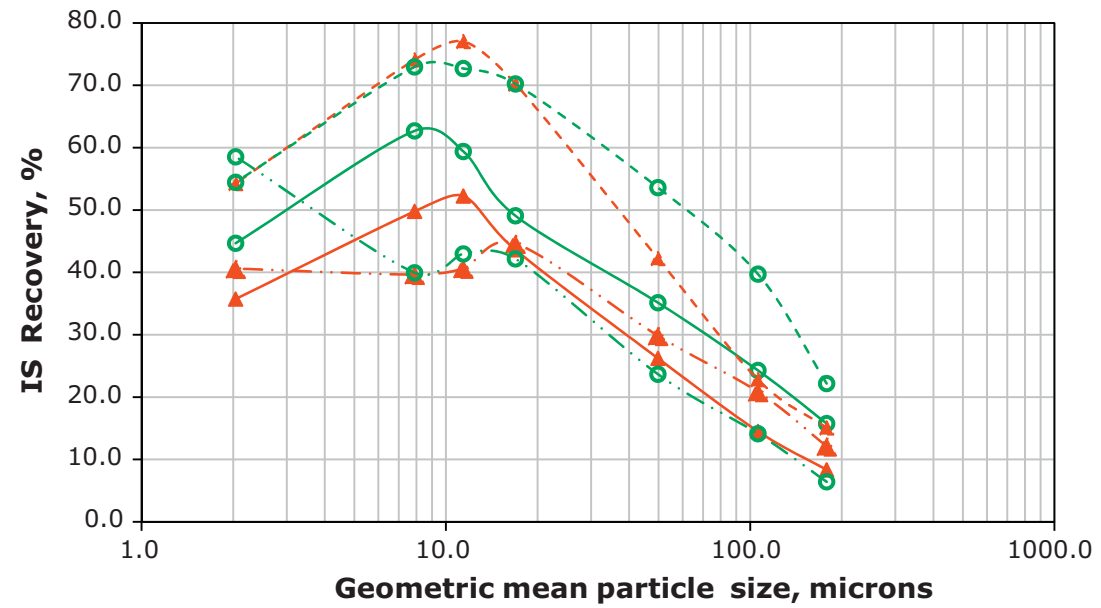

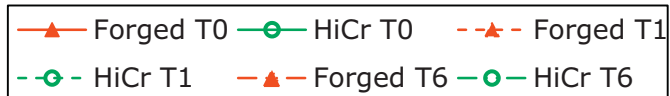

Fig. 5. Iron sulphide size by size recovery for T0, T1 and T6 samples ground with forged steel and high chrome media.

size recovery for $\mathrm{T} 0, \mathrm{~T} 1$ and $\mathrm{T} 6$ samples comparing forged steel and high chrome media are presented in Figs. 4 and 5 for copper and iron sulphide respectively.

The feed distribution data (Table 6) indicate that most of the copper and iron sulphides are present in the intermediate fractions with little amounts $(<10 \%)$ at both end of the size spectrum.

The recovery versus size curves show typical behaviour, with high recoveries for the intermediate $(-75 /+10 \mu \mathrm{m})$ size fractions and decreases for the fine $(-10 \mu \mathrm{m})$ and coarse $(+75 \mu \mathrm{m})$ ends of the size spectrum. An examination of the copper data (Fig. 4) shows that at T0 the forged steel produced slightly higher recoveries of fines compared to the high chrome, but with lower coarse particle recoveries. The initial oxidation step (T1) resulted in significant losses in both the fine and coarse particle recoveries for both alloys, with the forged steel case continuing to show higher fine particle recoveries but lower coarse particle recoveries compared to the high chrome test. By the end of the oxidation period (T6) the recoveries of the $+10 \mu \mathrm{m}$ size fractions had dramatically 
deteriorated, with forged steel fairing marginally better than the high chrome case. However, it was interesting to note that the recovery of $-10 \mu \mathrm{m}$ particles markedly increased for both media, but the ore ground with high chrome grinding media produced a significant increase in recovery over that ground with forged steel.

In terms of the pyrite flotation response, the data (Fig. 5) exhibited the same characteristic curve as for copper. In this case, the strongest recoveries occurred in the $-20 /+8 \mu \mathrm{m}$ (intermediate) size fractions, then decreased either side of this in the fine $(-8 \mu \mathrm{m})$ and coarse $(+20 \mu \mathrm{m})$ size fractions. At T0 the test performed with high chrome grinding media produced higher iron sulphide recoveries across all size fractions compared with the forged steel case. At the beginning of oxidation (T1) the iron sulphide recoveries were increased considerably across all size fractions compared to the T0 tests, suggesting that the iron sulphides were inadvertently activated. The difference between the two media types was predominantly in the coarse size fractions where the recovery of coarse pyrite was enhanced when grinding with high chrome grinding media. At the end of the oxidation period (T6) the iron sulphide recoveries across most size fractions had dropped back to levels for forged steel at T0. In this case, the forged steel data showed marginally higher iron sulphide recoveries of coarse particles when compared to the high chrome case. However, the high chrome data showed a marked increase in iron sulphide recoveries in the fine fractions.

It should be noted that the recovery of $-50 \mu \mathrm{m}$ iron sulphide particles for both media types, at all three oxidation conditions, was greater than water recovery ( $22 \%$ for T0 and $28 \%$ for T6). This suggests that the dominant mechanism by which these particles were recovered was by genuine flotation, and not entrainment.

\section{Discussion}

The results have shown that the type of grinding environment and the resulting pulp chemistry drive the flotation performances of the ore for each oxidation degree tested. At each oxidation step, high chrome media produced more oxidative pulp chemistry with lower levels of iron extracted by EDTA, and better flotation performances than that obtained with forged steel media.

It is most likely that the pyrite activation during the initial month of oxidation (T1 and T2) was due to copper activation as it corresponds to the peak of copper leached in the percolating solution which would have adsorbed on the pyrite surface, activating it. The size by size data showed that this activation by copper improved pyrite flotation regardless of the size fraction for both grinding environments. After two months of oxidative treatment, the acid neutralisation by the gangue was completed (Fig. 1), the pulp potential markedly dropped (Table 2 ), and the flotation kinetics for copper halved for the forged steel media. As the oxidation of the ore progressed (T3, T4 and T5), the metallurgical performances deteriorated for both media tested. The metallurgy is likely to have been impaired by a shift of grinding chemistry to more reducing conditions. In addition, the decrease of EDTA Fe extracted with forged steel media most probably indicates a decrease in the number of galvanic interactions taking place between the partially oxidised sulphides and the grinding media, reducing the number of iron ions released through media corrosion.

Finally, by the end of the oxidation process, when the ore was heavily oxidised and the copper flotation strongly deteriorated, the pulp chemistry was found to be similar for both grinding media, with similar copper flotation performances observed. In terms of pyrite selectivity, the selectivity index was still showing better selectivity of chalcopyrite against pyrite with high chrome media but to a much lesser extent than that obtained with the non-oxidised sample. This tends to suggest that when sulphide minerals become heavily oxidised, fewer galvanic interactions between the sulphide minerals and grinding media occurs; both media generating similar pulp chemistry and hence similar flotation performances of the ore.

\section{Conclusions}

Most of the experimental works reported in the literature separate the influence of the type of grinding media and ore weathering on sulphides flotation. This study intends to understand the combined effects of these two parameters.

The results have shown that the grinding pulp chemistry affects the flotation performance of the ore at each oxidation stage. During most of the oxidation period, high chrome media resulted in better copper flotation and better selectivity of chalcopyrite against pyrite through generation of more optimal pulp chemistry than that obtained with forged steel media. Regardless of the phenomena taking place in the percolation column during the entire time of the experiments, high chrome media delivered more stable pulp chemistry, not only at the ball mill discharge but also at the flotation feed. This can be of importance for controlling continuous operations at plant scale.

At the start of the oxidation period, it was observed that weak ore oxidation resulted in strong pyrite activation through adsorption of soluble copper released in the percolating solution. At the end of the experimental period (after 16 months), both grinding media generated similar pulp chemistry and copper flotation performances of the ore, suggesting that when sulphide minerals are strongly oxidised, less galvanic interactions occur during grinding.

\section{Acknowledgments}

The authors wish to thank the University of Liège and Magotteaux personnel for their help with the laboratory work. We also gratefully acknowledge Magotteaux for giving permission to publish this paper.

\section{References}

Adam, K., Natarajan, K.A., Iwasaki, I., 1984. Grinding media wear and its effect on the flotation of sulfide minerals. Int. J. Miner. Process. 12, 39-54.

Barzyk, W., Malysa, K., Pompianowski, A., 1981. The influence of surface oxidation of chalcocite on its floatability and ethyl xanthate sorption. Int. J. Miner. Process. 8, 17-29.

Boon, M., 2001. The mechanism of 'direct' and 'indirect' bacterial oxidation of sulphide minerals. Hydrometallurgy 62, 67-70.

Bruckward, W.J., Sparrow, G.J., Woodcock, J.T., 2011. A review of the effects of the grinding environment on the flotation of copper sulphides. Int. J. Miner. Process. 100, 1-13.

Buckley, A.N., Woods, R., 1984. An X-ray photoelectron spectroscopic study of the oxidation of chalcopyrite. Aust. J. Chem. 37, 2403-2413.

Chandra, A.P., Gerson, A.R., 2009. A review of the fundamental studies of the copper activation mechanism for selective flotation of the sulfide minerals, sphalerite and pyrite. Adv. Colloid Interface Sci. 145, 97-110.

Clark, D.W., Newell, A.J.H., Chilman, G.F., Capps, P.G., 2000. Improving flotation recovery of copper sulphides by nitrogen gas and sulphidisation conditioning. Miner. Eng. 13, 1197-1206.

Clarke, P., Fornasiero, D., Ralston, J., Smart, R.S.C., 1995. A study of the removal of oxidation products from sulphide mineral surfaces. Miner. Eng. 8, 1347-1357.

Ekmekçi, Z., Buswell, M.A., Bradshaw, D.J., Harris, P.J., 2005. The value and limitations of electrochemical measurements in precious metal ores. Miner. Eng. 18, 825-831.

Gonçalves, K.L.C., Andrade, V.L.L., Peres, A.E.C., 2003. The effect of grinding conditions on the flotation of a sulphide copper ore. Miner. Eng. 16, 1213-1216.

Grano, S., 2009. The critical importance of the grinding environment on fine particle recovery in flotation. Miner. Eng. 22, 386-394.

Greet, C.J., Small, G.L., Steinier, P., Grano, S.R., 2004. The Magotteaux Mill ${ }^{\circledR}$. investigating the effect of grinding media on pulp chemistry and flotation performance. Miner. Eng. 17, 891-896.

Guy, P.J., Trahar, W.J., 1985. The effect of oxidation and mineral interaction on sulphide flotation. In: Forrsberg, K.S.E. (Ed.), Flotation of Sulphide Minerals. Elsevier, Amsterdam, pp. 91-110. 
Huang, G., Grano, S., 2005a. Galvanic interaction between grinding media an arsenopyrite and its effect on flotation. Part I. Quantifying galvanic interaction during grinding. Int. J. Miner. Process. 78, 182-197.

Huang, G., Grano, S., 2005b. Galvanic interaction between grinding media and arsenopyrite and its effect on flotation. Part II. Effect of grinding on flotation. Int. J. Miner. Process. 78, 198-213.

Lascelles, D., Finch, J.A., 2002. Quantifying accidental activation. Part I. Cu ion production. Miner. Eng. 15, 567-571.

Luttrell, G.H., Yoon, R.H., 1984a. Surface oxidation of the collectorless flotation of chalcopyrite. Colloids Surf. 12, 239-254.

Luttrell, G.H., Yoon, R.H., 1984b. The collectorless flotation of chalcopyrite ores using sodium sulfide. Int. J. Miner. Process. 13, 271-283.

Owusu, C., Abreu, S.B., Skinner, W., Addai-Mensah, J., Zani, M., 2014. The influence of pyrite content on the flotation of chalcopyrite/pyrite mixtures. Miner. Eng. 55 87-95.

Peng, Y., Grano, S., Fornasiero, D., Ralston, J., 2003. Control of grinding conditions in the flotation of chalcopyrite and its separation from pyrite. Int. J. Miner. Process. 69, 87-100.

Peng, Y., Zhao, S., 2011. The effect of surface oxidation of copper sulfide minerals on clay slime coating in flotation. Miner. Eng. 24, 1687-1693.

Ralston, J., Fornasiero, D., Grano, S., 2007. Pulp and solution chemistry. In: Fuerstenau, M.C., Jameson, G., Yoom, R.H. (Eds.), Froth Flotation: A Century of Innovation. Society for Mining, Metallurgy and Exploration Inc, p. 891.

Rumball, J.A., Richmond, G.D., 1996. Measurement of oxidation in a base metal flotation circuit by selective leaching with EDTA. Int. J. Miner. Process. 48, 1-20.

Senior, G.D., Trahar, W.J., 1991. The influence of metal hydroxides and collector on the flotation of chalcopyrite. Int. J. Miner. Process. 33, 321-341.
Smart, R., St, C., 1991. Surface layers in base metal sulfide flotation. Miner. Eng. 4, 891-909.

Smart, R.St.C., Amarantidis, J., Skinner, W., Prestidge, C.A., La Vanier, L., Grano, S., 1998. Surface analytical studies of oxidation and collector adsorption in sulphide mineral flotation. Scan. Microsc. 12 (4), 553-583.

Todd, E.C., Sherman, D.M., Purton, J.A., 2003. Surface oxidation of chalcopyrite (CuFeS2) under ambient atmospheric and aqueous ( $\mathrm{pH} 2-10)$ conditions: $\mathrm{Cu}, \mathrm{Fe}$ L and O K-edge X-ray spectroscopy. Geochim. Cosmochim. Acta 67, 2137-2146.

Tolley, W., Kotlyar, D., Van Wagoner, R., 1996. Fundamental electrochemical studies of sulphide mineral flotation. Min. Eng. 9, 603-637.

Vaughan, D.J., England, K.E.R., Kelsall, G.H., Yin, Q., 1995. Electrochemical oxidation of chalcopyrite $\left(\mathrm{CuFeS}_{2}\right)$ and the related metal-enriched derivatives $\mathrm{Cu}_{4} \mathrm{Fe}_{5} \mathrm{~S}_{8}$, $\mathrm{Cu}_{9} \mathrm{Fe}_{9} \mathrm{~S}_{16}$ and $\mathrm{Cu}_{9} \mathrm{Fe}_{8} \mathrm{~S}_{16}$. Am. Mineral. 80, 725-731.

Von Oertzen, G.U., Skinner, W., Nesbitt, H.W., Pratt, A.R., Buckley, A.N., 2007. Cu adsorption on pyrite (1 0 0): Ab initio and spectroscopic studies. Surf. Sci. 601, 5794-5799.

Watling, H.R., 2006. The bioleaching of sulphide minerals with emphasis on copper sulphides - a review. Hydrometallurgy 84, 81-108.

Walker, G.W., Walters, C.P., Richardson, P.E., 1986. Hydrophobic effects of sulfur and xanthate on metal and mineral surfaces. Int. J. Miner. Process. 18, 119-137.

Woods, R., 2003. Electrochemical potential controlling flotation. Int. J. Miner. Process. 72, 151-162.

Woods, R., 2010. Electrochemical aspects of sulphide mineral flotation. In: Greet, C.J. (Ed.), Flotation Plant Optimisation: A Metallurgical Guide to Identifying and Solving Problems in Flotation Plants, Spectrum Series, vol. 16. The Australasian Institute of Mining and Metallurgy, Melbourne, p. 210.

Xu, M., 1998. Modified flotation rate constant and selectivity index. Miner. Eng. 11 (3), 271-278. 